\title{
MEASURING VOLATILITY OF NIFTY50 AND SENSEX UNDER DIFFERENT ERROR DISTRIBUTION METHODS OF E-GARCH FOR THE PERIOD BETWEEN 2011 TO 2016.
}

\author{
Dr. Vijayakumari Joseph* 1, Ms. A.Amali Vinupriyadharshini**2 \\ 1*Asst. Professor\& Research Supervisor, Department of Commerce, Madras Christian College, \\ Chennai-59. \\ 2**Research Scholar, Department of Commerce, Madras Christian College, Chennai - 59 .
}

\begin{abstract}
:
Volatility has always been a part and parcel of stock market. Understanding the volatility is very difficult though measuring it is not impossible. Choosing the right method to meausre the volatility is very crucial and important to get the reliable and accurate results. This study aims at measuring volatility of Nifty50 and Sensex under different error distribution methods of E-GARCH model. E-GARCH is one of the reliable ARCH models that measures persistent volatility and asymmetric effects. This paper bring out the best suited model for Nifty50 and Sensex in measuring the volatility under different error distribution method of E-GARCH model.
\end{abstract}

Keywords: Volatility, Asymmetric effect, GARCH.

\section{Introduction:}

Volatility has always been a part and parcel of stock market. Understanding the volatility is very difficult though measuring it is not impossible. Choosing the right method to meausre the volatility is very crucial and important to get the reliable and accurate results. This study aims at measuring volatility of Nifty50 and Sensex under different error distribution metholds of E-GARCH model. E-GARCH is one of the reliable ARCH models that measures persistent volatility and asymmetric effects. This paper bring out the best suited model for Nifty50 and Sensex in measuring the volatility under different error distribution method of E-GARCH model.

E-GARCH is established to measure the asymmetric effect. It refers to Exponential Generalised Auto Regressive Conditional Heteroskedasticity. ARCH is the fundamental for all the trending GARCH models, which simplies the meaning of lagged values having an impact on the current value. Heteroskedasticity is to test the variance of volatility. By heteroskedastic, it means that there is no constant variance of the fluctuation. Engle (1986) was the first to assume the varying variance from which many volatility models have been developed, though, Nelson (1991) was the first to propound the EGARCH model.

$$
\begin{aligned}
\log \left(h_{t}\right)=C+ & \sum_{i-1}^{q} \eta_{i}\left|\frac{u_{t-1}}{\sqrt{h_{t-1}}}\right|+\sum_{i-1}^{q} \lambda_{i}\left|\frac{u_{t-1}}{\sqrt{h_{t-1}}}\right| \\
& +\sum_{k=1}^{p} \theta_{k} \log \left(h_{t-k}\right)
\end{aligned}
$$

Where $\log h_{t}=\log$ of variance series

$$
\begin{aligned}
& C=\text { Constant } \\
& \eta=\text { Arch Effects } \\
& \lambda=\text { Asymmetric effects } \\
& \theta=\text { GARCH effects }
\end{aligned}
$$

\section{Review of Literature}

HojatallahGoudarzi, Ramanarayanan C.S (2011). This paper studied the effects of good and bad news on volatility in Indian stock market with special reference to BSE. It used Asymmetric ARCH models to study the impact of good news and bad news on volatility. The study was done for 10 years covering the period of financial crisis of 2008-09. BSE 500 index was used and found to have an impact of conditional volatility asymmetrically. This study found that bad news had more impact on volatility than the good news. T-Garch and E-Garch models were the best fit for Asymmetric volatility. BSE 500 index found to have stylized facts like 
volatility clustering, leverage effects and leptokurtosis just like developed stock markets. This study recommended to restructure the price limits, volume quotas considering the economy and stock market trading cycles and calls for more deeper, more efficient and well -regulated financial market.

ManiklalAdhikary, Shyamal Saha (2016). This paper studied the volatility present in daily returns between then NSE Nifty and BSE Sensex for the period 1990-2013. Everyday closing prices of both the indices were considered. Asymmetric Garch models were used to prove volatility clustering and leverage effects in the time series. GJR-Garch model was found to be the best fit for both the indices. The time series exhibit volatility clusters in consistent with Fama's observation (1965) where large returns are followed by large returns and small returns follow small returns. The study found strong evidences of time varying volatility. High and low volatilities tend to cluster and they were persistent.

(Karthika \& Kathikeyan, 2016) Various conditional heteroskedasticity models were modeled and compared to study the volatility of Nifty 50 index for a period of one year from Jan'15 to Dec'15. The objective of the study was to estimate the volatility of Nifty 50 index using GARCH models. The study finds the presence of Asymmetry in stock returns, which means bad news has more effect on volatility. The study finds $\operatorname{GARCH}(1,1)$ model to fit the best in capturing the symmetrical volatility and E-GARCH and T-GARCH models captures asymmetric volatility efficiently.

(Srinath, 2015). The main objective of this paper was to study the presence of volatility and its persistence and also to investigate the presence of Asymmetry in Indian stock market. Two major stock markets of India are BSE and NSE and their indices were used for data analysis. The period of study was from April 2004 - March 2014. The study observed that ARCH effects were weak when compared to GARCH effects which implies that reaction to shocks of conditional variances are weak. The study analysed a steady growth in both the markets from 2004 to 2008. And as known 2009 was a bad time for stock holders, there was poor performance in the stock market. Slowly the market developed and improved after 2009 crises. This study found that the market was performing good and the stock prices started to increase considerably. Also the GARCH model proved the presence of volatility in Indian stock market and asymmetrically responding to negative shock.

(kumar, 2008) This paper studies Asymmetric volatility in Indian stock market by considering four indices Sensex, BSE 100, S\&P CNX 500 and S\&P CNX Nifty for the period between April 1995 to Dec 2007. A comparative study among Asymmetric and Symmetric models were done and concludes that GARCH was more suitable to project the Asymmetric volatility than the other GARCH models. This study also uses the news impact curve to support the presence of Asymmetric volatility. Forecast encompassing test by Chong \& Henry (1986) was used to test the forecasting power of these models. All these models prove the presence of Asymmetry in the stock market. And specially EGarch proves to fit the best for Asymmetric volatility.

\section{Data Analysis}

The data is taken from the official website of National Stock Exchange and Bombay Stock Exchange for the period between 2011 to 2016. Daily closing prices were taken and daily returns werecalculated using

$$
r t=\log P(t)-\log P(t-1)
$$

Where,

$$
\begin{aligned}
\mathrm{rt} & =\text { Return } \\
\mathrm{P}(\mathrm{t}) & =\text { Today's price } \\
\mathrm{P}(\mathrm{t}-1) & =\text { Yesterday's price }
\end{aligned}
$$

Descriptive Statistics

Table 1: Descriptive Statistics

\begin{tabular}{|l|l|l|}
\hline Statistics & Sensex & Nifty 50 \\
\hline
\end{tabular}




\begin{tabular}{|l|l|l|} 
Mean & 0.00755 & 0.00832 \\
\hline Median & 0.01142 & 0.01016 \\
\hline Maximum & 1.60837 & 1.62338 \\
\hline Minimum & -2.6578 & -2.648 \\
\hline Std. Dev. & 0.4471 & 0.45438 \\
\hline Skewness & -0.149 & -0.158 \\
\hline Kurtosis & 4.58449 & 4.55099 \\
\hline Jarque-Bera & 161.057 & 155.232 \\
\hline Probability & 0 & 0 \\
\hline Sum Sq. Dev. & 297.051 & 306.799 \\
\hline Observations & 1487 & 1487 \\
\hline
\end{tabular}

In table 1, the results of descriptive statistics is discussed. For a period of six years, the number of observations were 1487 . The mean of daily returns for Sensex was 0.00755 with a standard deviation at 0.4471 . It has negative skewness at -0.149 with kurtosis more than the normal level at 4.58449 which is leptokurtic. The JarqueBera test gives a result of 161.057 with zero probability value which confirms that the data is not normally distributed. Likewise, the mean returns for Nifty 50 is 0.00832 with standard deviation at 0.45438 . It is negatively skewed at -0.158 and leptokurtic at 4.55099 . The Jarque-Bera test confirms that the data is not normally distributed at $\mathrm{P}$ value 0 with $\mathrm{JB}$ value at 155.232 .

Graph1

\section{SENSEX}

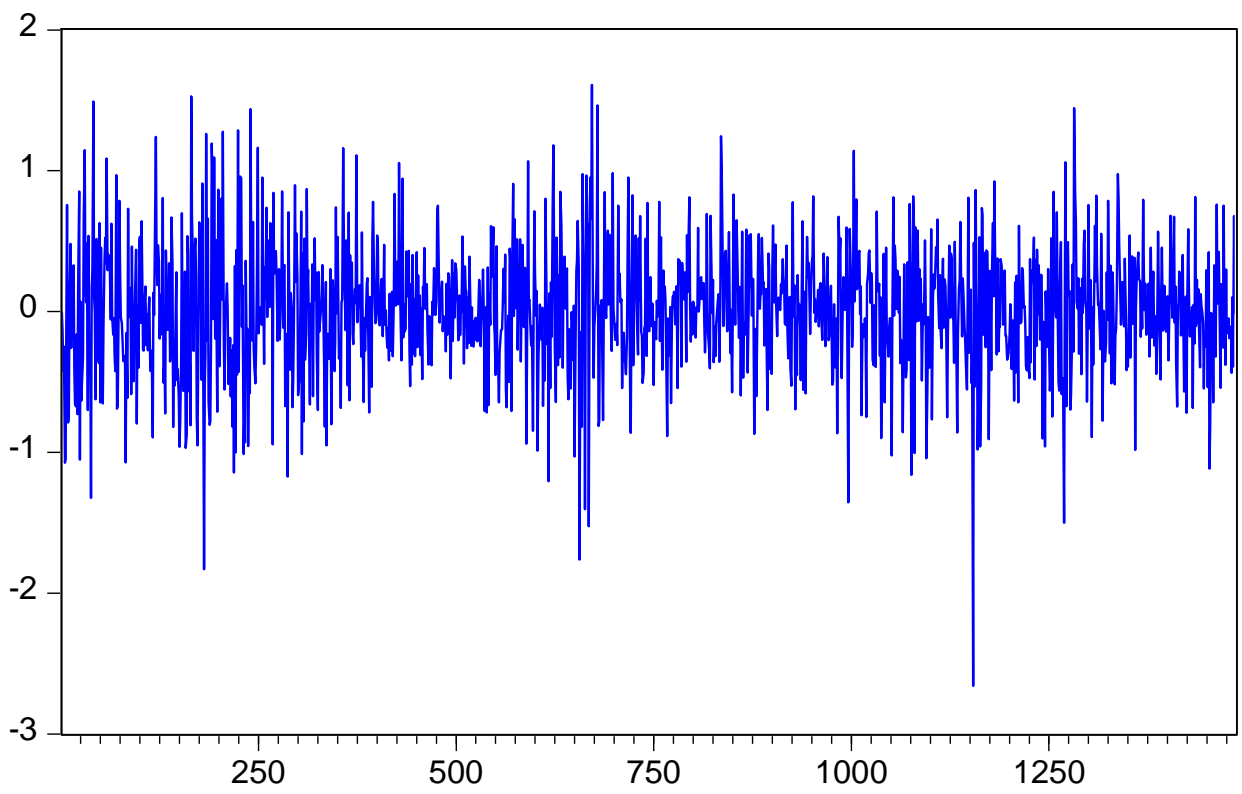

Graph2 
NIFTY50

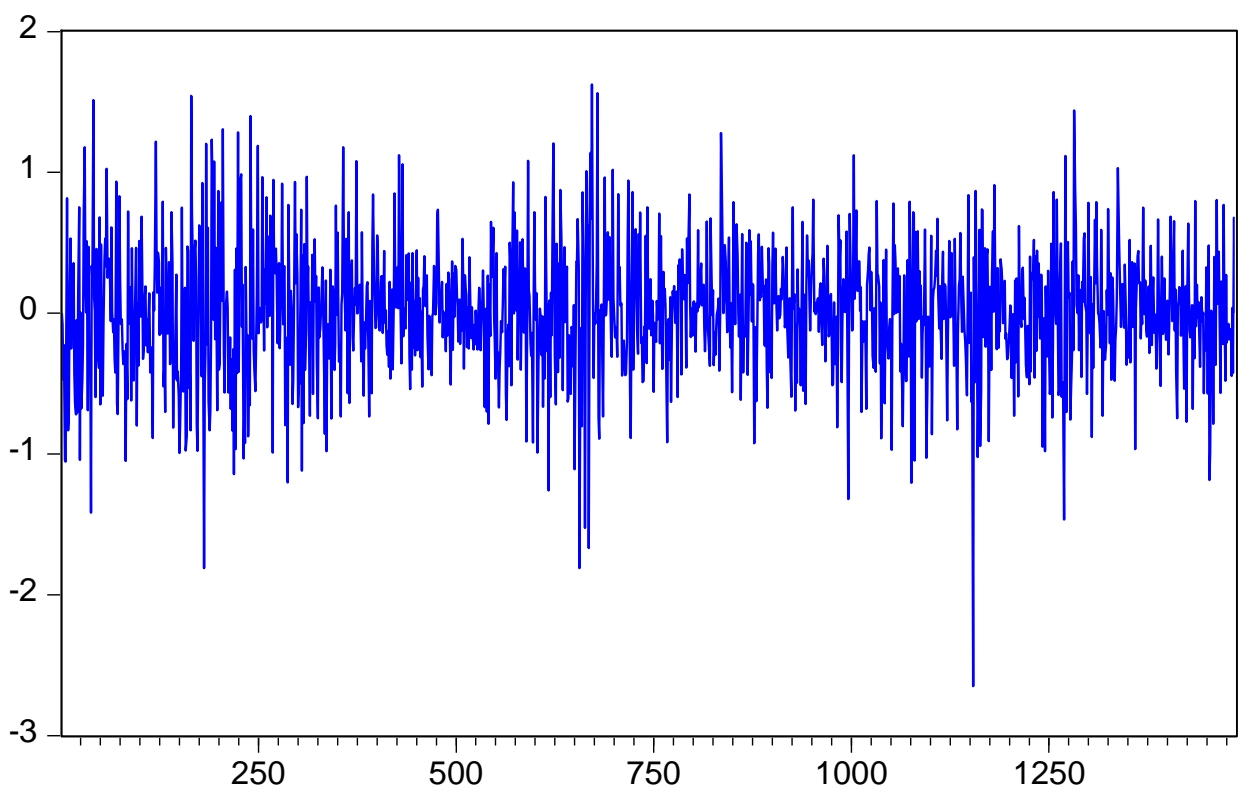

For both the markets Sensex and Nifty50, the data shows the presence of volatility clustering where larger values are followed by larger values; mean reversion that returns fluctuates around the mean and pass through zero and fat tails that confirms larger values more than the mean value.

Table:2 ARCH - LM Test

The data was run through the Augmented Dickey Fuller test to confirm the absence of unit root and confirm the stationarity. The ADF test gives the value of -35.58546 for Sensex and -35.4803 for Nifty50 with significant $p$ values. This confirms that the data is stationary.

\begin{tabular}{|l|l|l|l|}
\hline \multicolumn{3}{|l|}{ Heteroskedasticity Test: ARCH } \\
\hline F-statistic & 10.44661 & Prob. F(3,1480) & 0 \\
\hline Obs*R-squared & 30.7729 & Prob. Chi-Square(3) & 0 \\
\hline
\end{tabular}

ARCH-LM test is done to test the presence of ARCH effects. The $\mathrm{F}$ statistics with respective significant $\mathrm{P}$ value confirms the presence of ARCH effects in the data, and therefore E-GARCH can be performed further.

Exponential GARCH (E-GARCH)
E-GARCH measures the volatility and its asymmetric effect. It is estimated using Maximum Likelihood ARCH method under 5 different error distribution methods namely Normal Gaussian, Student's t, Generalized error, Student's t with fixed degrees of freedom, Generalized error with fixed parameters. All these are done to analyze the best fit model.

Table:3 Mean equation for Sensex

\begin{tabular}{|l|l|l|l|l|l|}
\hline $\begin{array}{l}\text { Sensex/Mean } \\
\text { equation }\end{array}$ & Gaussian & Student's t & $\begin{array}{l}\text { Generalized } \\
\text { error }\end{array}$ & $\begin{array}{l}\text { Student's th t } \\
\text { with fixed df }\end{array}$ & $\begin{array}{l}\text { GED with fixed } \\
\text { parameter }\end{array}$ \\
\hline
\end{tabular}




\begin{tabular}{|c|c|c|c|c|c|}
\hline $\begin{array}{l}\text { Constant co- } \\
\text { efficient }\end{array}$ & $\begin{array}{l}0.005772 \\
{[0.010963]} \\
(0.59850)\end{array}$ & $\begin{array}{l}0.009105 \\
{[0.010609]} \\
(0.3908)\end{array}$ & $\begin{array}{l}0.009892 \\
{[0.010059]} \\
(0.3254)\end{array}$ & \begin{tabular}{|l}
0.009050 \\
{$[0.010663]$} \\
$(0.3960)$
\end{tabular} & $\begin{array}{l}0.009282 \\
{[0.010377]} \\
(0.3711)\end{array}$ \\
\hline $\operatorname{AR}(1)$ & $\begin{array}{l}0.104830 \\
{[0.028496]} \\
(0.0002)\end{array}$ & $\begin{array}{l}0.599357 \\
{[0.280869]} \\
(0.0328)\end{array}$ & $\begin{array}{l}0.128550 \\
{[0.006274]} \\
(0.0000)\end{array}$ & $\begin{array}{l}0.587652 \\
{[0.281035]} \\
(0.0365)\end{array}$ & $\begin{array}{l}0.712983 \\
{[0.295116]} \\
(0.0157)\end{array}$ \\
\hline $\operatorname{AR}(2)$ & $\begin{array}{l}-0.937084 \\
{[0.026155]} \\
(0.0000)\end{array}$ & $\begin{array}{l}0.248644 \\
{[0.257892]} \\
(0.3350)\end{array}$ & $\begin{array}{l}-0.979567 \\
{[0.005582]} \\
(0.0000)\end{array}$ & \begin{tabular}{|l}
0.259143 \\
{$[0.257862]$} \\
$(0.3149)$
\end{tabular} & $\begin{array}{l}0.152897 \\
{[0.274868]} \\
(0.5780)\end{array}$ \\
\hline $\mathrm{MA}(1)$ & $\begin{array}{l}-0.081940 \\
{[0.024462]} \\
(0.0008)\end{array}$ & $\begin{array}{l}-0.522670 \\
{[0.272863]} \\
(0.0554)\end{array}$ & $\begin{array}{l}-0.120719 \\
{[0.004770]} \\
(0.0000)\end{array}$ & \begin{tabular}{|l}
-0.511380 \\
{$[0.272776]$} \\
$(0.0608)$
\end{tabular} & $\begin{array}{l}-0.637497 \\
{[0.289888]} \\
(0.0279)\end{array}$ \\
\hline $\operatorname{MA}(2)$ & $\begin{array}{l}0.953330 \\
{[0.023185]} \\
(0.0000)\end{array}$ & $\begin{array}{l}-0.324607 \\
{[0.249034]} \\
(0.1924)\end{array}$ & $\begin{array}{l}0.990623 \\
{[0.004109]} \\
(0.0000)\end{array}$ & $\begin{array}{l}-0.334654 \\
{[0.248759]} \\
(0.1785)\end{array}$ & $\begin{array}{l}-0.230129 \\
{[0.268915]} \\
(0.3921)\end{array}$ \\
\hline
\end{tabular}

[ ] denotes standard error

( ) denotes probability value

Auto-regression (1) and Auto regression (2) are previous values of Sensex, which are significant or otherwise in determining the return of the Sensex. MA(1) and MA(2) refers to the moving averages or errors of previous days in determining the return of the Sensex.
Among all the error distribution methods, the constant co-efficient is statistically insignificant in determining the mean of the Sensex. But the auto-regressive values and moving averages of previous days play a significant role in determining the return of Sensex under the Gaussian and Generalized error distribution methods but proves to be statistically insignificant under student's t distribution, student's $t$ with fixed df and GED with fixed parameters methods.

Table: 4 Variance equation of Sensex

\begin{tabular}{|c|c|c|c|c|c|}
\hline $\begin{array}{l}\text { Sensex/Variance } \\
\text { equation }\end{array}$ & Gaussian & Student's t & $\begin{array}{l}\text { Generalized } \\
\text { error }\end{array}$ & $\begin{array}{l}\text { Student's } t \\
\text { with fixed df }\end{array}$ & $\begin{array}{l}\text { GED with } \\
\text { fixed } \\
\text { parameter }\end{array}$ \\
\hline $\begin{array}{l}\text { Constant co- } \\
\text { efficient }\end{array}$ & $\begin{array}{l}-0.101488 \\
{[0.021447]} \\
(0.0000)\end{array}$ & $\begin{array}{l}-0.095363 \\
{[0.023654]} \\
(0.0001)\end{array}$ & $\begin{array}{l}-0.091254 \\
{[0.024532]} \\
(0.0002)\end{array}$ & $\begin{array}{l}-0.094985 \\
{[0.023237]} \\
(0.0000)\end{array}$ & $\begin{array}{l}-0.095063 \\
{[0.025082]} \\
(0.0002)\end{array}$ \\
\hline $\mathrm{ARCH}$ & $\begin{array}{l}0.069811 \\
{[0.018758]} \\
(0.0002)\end{array}$ & $\begin{array}{l}0.070233 \\
{[0.022058]} \\
(0.0015)\end{array}$ & $\begin{array}{l}0.064095 \\
{[0.022457]} \\
(0.0043)\end{array}$ & $\begin{array}{l}0.069339 \\
{[0.021376]} \\
(0.0012)\end{array}$ & $\begin{array}{l}0.068123 \\
{[0.022687]} \\
(0.0027)\end{array}$ \\
\hline E-GARCH & $\begin{array}{l}-0.084386 \\
{[0.011778]} \\
(0.0000)\end{array}$ & $\begin{array}{l}-0.087899 \\
{[0.016452]} \\
(0.000)\end{array}$ & $\begin{array}{l}-0.083248 \\
{[0.015829]} \\
(0.0000)\end{array}$ & $\begin{array}{l}-0.086435 \\
{[0.015931]} \\
(0.0000)\end{array}$ & $\begin{array}{l}-0.085867 \\
{[0.015938]} \\
(0.0000)\end{array}$ \\
\hline GARCH & $\begin{array}{l}0.972315 \\
{[0.006110]} \\
(0.0000)\end{array}$ & $\begin{array}{l}0.976141 \\
{[0.006851]} \\
(0.0000)\end{array}$ & $\begin{array}{l}0.976178 \\
{[0.006978]} \\
(0.0000)\end{array}$ & $\begin{array}{l}0.976226 \\
{[0.006700]} \\
(0.0000)\end{array}$ & $\begin{array}{l}0.975462 \\
{[0.007163]} \\
(0.0000)\end{array}$ \\
\hline
\end{tabular}


The variance equation of E-GARCH gives negative values confirming the presence of asymmetric effects in Sensex with values $-0.084386,-0.087899,-0.083248$, 0.086435 and -0.085867 under Gaussian, Student's t,
Generalized error, Student's t with fixed df, and GED with fixed parameter methods respectively. The ARCH and GARCH values put together evidences persistent volatility in the market with values 1 or more than

Table : 5 Mean equation of Nifty50

\begin{tabular}{|c|c|c|c|c|c|}
\hline $\begin{array}{l}\text { Nifty/Mean } \\
\text { equation }\end{array}$ & Gaussian & Student's t & $\begin{array}{l}\text { Generalised } \\
\text { error }\end{array}$ & $\begin{array}{l}\text { Student's t } \\
\text { with fixed } \\
\text { df }\end{array}$ & $\begin{array}{l}\text { GED with } \\
\text { fixed } \\
\text { parameter }\end{array}$ \\
\hline $\begin{array}{l}\text { Constant co- } \\
\text { efficient }\end{array}$ & $\begin{array}{l}0.007741 \\
{[0.011096]} \\
(0.4854)\end{array}$ & $\begin{array}{l}0.010153 \\
{[0.011144]} \\
(0.3623)\end{array}$ & $\begin{array}{l}0.010803 \\
{[0.010201]} \\
(0.2896)\end{array}$ & $\begin{array}{l}0.008973 \\
{[0.011480]} \\
(0.4344)\end{array}$ & $\begin{array}{l}0.010887 \\
{[0.011002]} \\
(0.3224)\end{array}$ \\
\hline $\operatorname{AR}(1)$ & $\begin{array}{l}0.100995 \\
{[0.025503]} \\
(0.0001)\end{array}$ & $\begin{array}{l}0.573504 \\
{[0.267877]} \\
(0.0323)\end{array}$ & $\begin{array}{l}0.128106 \\
{[0.006671]} \\
(0.0000)\end{array}$ & $\begin{array}{l}0.550265 \\
{[0.025240]} \\
(0.0000)\end{array}$ & $\begin{array}{l}0.621153 \\
{[0.281188]} \\
(0.0272)\end{array}$ \\
\hline $\mathrm{AR}($ & $\begin{array}{l}-0.938542 \\
{[0.024111]} \\
(0.0000)\end{array}$ & $\begin{array}{l}0.276535 \\
{[0.241581]} \\
(0.2523)\end{array}$ & $\begin{array}{l}-0.978223 \\
{[0.005911]} \\
(0.0000)\end{array}$ & $\begin{array}{l}0.387305 \\
{[0.025183]} \\
(0.0000)\end{array}$ & $\begin{array}{l}0.230600 \\
{[0.254731]} \\
(0.3653)\end{array}$ \\
\hline MA(1) & $\begin{array}{l}-0.075172 \\
{[0.021520]} \\
(0.0005)\end{array}$ & $\begin{array}{l}-0.490294 \\
{[0.259201]} \\
(0.0585)\end{array}$ & $\begin{array}{l}-0.120284 \\
{[0.005046]} \\
(0.0000)\end{array}$ & $\begin{array}{l}-0.467456 \\
{[0.005480]} \\
(0.0000)\end{array}$ & $\begin{array}{l}-0.540070 \\
{[0.274045]} \\
(0.0488)\end{array}$ \\
\hline $\mathrm{MA}(2)$ & $\begin{array}{l}0.955488 \\
{[0.020921]} \\
(0.0000)\end{array}$ & $\begin{array}{l}-0.353801 \\
{[0.231376]} \\
(0.1262)\end{array}$ & $\begin{array}{l}0.989584 \\
{[0.004334]} \\
(0.0000)\end{array}$ & $\begin{array}{l}-0.471641 \\
{[0.005169]} \\
(0.0000)\end{array}$ & $\begin{array}{l}-0.305921 \\
{[0.245588]} \\
(0.2129)\end{array}$ \\
\hline
\end{tabular}

[ ] denotes standard error

( ) denotes probability value

Among all the error distribution methods, the constant co-efficient is statistically insignificant in determining the mean of the Nifty50. But the auto-regressive values and moving averages of previous days play a significant role in determining the return of Nifty50 and proves to be statistically significant in determining the mean of Nifty50. $\operatorname{Lag}(2)$ values proves to be statistically significant except the student's $t$ distribution and GED with fixed parameters methods.

Table : 6Variance equation of Nifty

\begin{tabular}{|l|l|l|l|l|l|}
\hline $\begin{array}{l}\text { Nifty/Variance } \\
\text { equation }\end{array}$ & Gaussian & Student's t & $\begin{array}{l}\text { Generalised } \\
\text { error }\end{array}$ & $\begin{array}{l}\text { Student's t } \\
\text { with fixed } \\
\text { df }\end{array}$ & $\begin{array}{l}\text { GED with } \\
\text { fixed } \\
\text { parameter }\end{array}$ \\
\hline $\begin{array}{l}\text { Constant } \\
\text { efficient }\end{array}$ & -0.100694 & -0.089533 & -0.089940 & -0.092169 & -0.089138 \\
& {$[0.021233]$} & {$[0.022298]$} & {$[0.024241]$} & {$[0.022328]$} & {$[0.023549]$} \\
& $(0.0000)$ & $(0.0001)$ & $(0.0002)$ & $(0.0000)$ & $(0.0002)$ \\
\hline & 0.069811 & 0.066547 & 0.064025 & 0.069167 & 0.064649 \\
ARCH & {$[0.018758]$} & {$[0.021540]$} & {$[0.022881]$} & {$[0.020815]$} & {$[0.022244]$} \\
& $(0.0002)$ & $(0.0020)$ & $(0.0051)$ & $(0.0009)$ & $(0.0037)$ \\
\hline
\end{tabular}




\begin{tabular}{|l|l|l|l|l|l|} 
& -0.083733 & -0.088225 & -0.082890 & -0.090392 & -0.086858 \\
E-GARCH & {$[0.011276]$} & {$[0.015823]$} & {$[0.015062]$} & {$[0.015105]$} & {$[0.015280$} \\
& $(0.0000)$ & $(0.0000)$ & $(0.0000)$ & $(0.0000)$ & $(0.0000)$ \\
\hline \multirow{3}{*}{ GARCH } & 0.973204 & 0.976141 & 0.976415 & 0.977147 & 0.977063 \\
& {$[0.005741]$} & {$[0.006851]$} & {$[0.006662]$} & {$[0.006533]$} & {$[0.006446]$} \\
& $(0.0000)$ & $(0.0000)$ & $(0.0000)$ & $(0.0000)$ & $(0.0000)$ \\
\hline
\end{tabular}

The variance equation of E-GARCH gives negative values confirming the presence of asymmetric effects in Nifty50. The ARCH and GARCH values put together evidences persistent volatility in the market.

Findings

- The constant co-efficient is statistically insignificant in determining the mean of both the markets Sensex and Nifty50

- In determining the mean of Sensex, Gaussian and student's $t$ distribution proves to be statistically significant. This confirms that past values play a significant role in determining the current returns of the market.

- In determining the mean of Nifty, Gaussian, student's $t$ and student's $t$ with fixed df proves to be statistically significant. This confirms that lagged values play a crucial role in determining the future returns of the market.

- Both the markets shows signs of asymmetry under all the error distribution methods. The negative shocks influences more than the positive shocks in both the markets Sensex and Nifty50.

- The markets Sensex and Nifty50 experiences Persistent volatility and long memory prevails in both the markets.

- Residuals are normally distributed and statistically significant in determining the mean and variance equation of both the markets.

\section{References}

\section{References}

Adhikary, M., \& Saha, S. (2016). Indian stock market volatility- Asymmetric GARCH models. Asian
Journal of Research in Banking and Finance, 6(3), 1-25.

Dr. D.Paul Dhinakaran, "Exports and Imports

Stagnation in India During Covid-19- A

Review" GIS Business (ISSN: 1430-3663 Vol15-Issue-4-April-2020).

Asteriou, D., \& Hall, S. G. (2016). Applied

Econometrics. Palgrave Macmillan Education.

Goudarzi, H., \& Ramanarayanan, C. (2011). Modeling Asymmetric volatility in the Indian stock market. International Journal of Business and Management, 6(3), 221-231.

Gujarati, D. N., \& Porter, D. C. (2009). Basic Econometrics. New York: The McGraw -Hill Companies.

Karthika, P., \& Kathikeyan, P. (2016). Stock returns and volatility: Evidences from Nifty 50 index. Asian Journal of Research in Social sciences and Humanities, 6(5), 434-442.

kumar, M. P. (2008). The study of Asymmetric volatility in Indian equity market - A GARCH approach. Al-Barkaat Journal of Finance and Management, 1-20.

Ngozi, A. (2018, March 12). Crunch Econometrix. Retrieved from Youtube.com: https://www.youtube.com/watch?v=TB4m9M1 $\mathrm{sIJ0} \& \mathrm{t}=1 \mathrm{~s}$

Dr. D.Paul Dhinakaran, "Passengers impression towards Tamilnadu State Transport corporation"A Journal of road Transport, (ISSN: 2394-2495) Volume I, Issue X, JanuaryMarch 2017, P.1-10.

Srinath, R. (2015). Volatility in Indian stock market. Asian Journal of Research in Business Economics and Management, 5(2), 298-311. 